\title{
Philonsorbonne
}

12 | 2018

Année 2017-2018

\section{Towards a theory of action in Sartre's philosophy. From action to ethics}

André BARATA

\section{(2) OpenEdition \\ Journals}

Electronic version

URL: https://journals.openedition.org/philonsorbonne/1006

DOI: 10.4000/philonsorbonne.1006

ISSN: $2270-7336$

Publisher

Publications de la Sorbonne

\section{Printed version}

Date of publication: 1 January 2018

Number of pages: 125-137

ISSN: 1255-183X

\section{Electronic reference}

André BARATA, "Towards a theory of action in Sartre's philosophy. From action to ethics",

Philonsorbonne [Online], 12 | 2018, Online since 20 March 2018, connection on 08 June 2021. URL

http://journals.openedition.org/philonsorbonne/1006 ; DOI: https://doi.org/10.4000/philonsorbonne. 1006

(c) Tous droits réservés 


\title{
Towards a theory of action in Sartre's philosophy. From action to ethics
}

\author{
André BARATA \\ (University of Beira Interior, Portugal) \\ (LABCOM.IFP - Communication, Philosophy, Humanities)
}

In this reading, I will approach what could be argued as the core of a theory of action in Jean-Paul Sartre's thought, tackling its ethical implications. Throughout the analysis, I will outline elements that allow for an integrated perspective of Sartre's ethical thought. I will explore a few significant passages, mainly from Sartre's masterpiece - L'Etre et le Néant, his phenomenological ontology of 1943 - and occasionally from other works, both earlier and later.

My examination stems from two ontological considerations and develops along a set of points primarily delineating a Sartrean theory of action and ultimately a Sartrean ethics. These two underlying premises pertain to Sartre's thought on freedom and will, both quite originally defined from his phenomenological point of view. Both also frame the ensuing critical thoughts on Sartre's theory of action and Sartre's ethics.

\section{Freedom, not free will}

It is perhaps wisest to begin by precluding a misinterpretation of Sartre's understanding of freedom. For Sartre, freedom is ontological, which means that it is the very being of consciousness, of the for-itself (pour-soi). Conscious grasping of this free condition comes about through the experience of angst (angoisse).

This suggests at least two things: first, that Sartre's concept of freedom does not fit any of the usual options in the philosophical debate on free will. Sartre is admittedly not a determinist who proposes that present mental states 
would be caused by preceding mental states. On the contrary, for Sartre, present consciousness is determined only by itself, in its very presence. He sees past consciousness as inert, void of power to determine present consciousness. Might he instead be a compatibilist, believing determinism to be compatible with free will? $\mathrm{He}$ is not a compatibilist either, as that position implies an acceptance of determinism. The compatibilist perspective assumes the truth of determinism and investigates the role of free will in a deterministic world. But, precisely, determinism is outright rejected by Sartre. And he rejects it not merely the sense in which different effects could follow from the same causes, but from a more radical perspective whereby no cause/effect relation whatsoever is relevant to the phenomena of consciousness. Neither determinist, nor compatibilist, Sartre is no libertarian either on the matter of free will. According to the libertarian view, the admission of free will implies a refusal of determinism. While Sartre would agree that freedom implies such a refusal (at least as regards subjective existence), he quite simply does not equate freedom with free will. In fact, for Sartre, freedom as an ontological concept is rather removed from the idea of free will. Consciousness is free regardless of human will. Freedom is a transcendental condition for conscious being. That is not, for Sartre, the case with will. As such, the concept of free will makes little sense within Sartre's ontological frame.

\section{Will is witness, not agent}

The second consideration is related to the agential status of will. Yet again, Sartre disagrees with the more obvious representations. Namely, that of will (free or otherwise) as determining one's choice, deliberation and action. For Sartre, when will comes into play, "les jeux sont faits", evoking Julius Caesar's Alea iacta est, the die is cast.

In so considering will, Sartre diverges from a traditional representation of human action according to which, since action is rational, it is primarily determined by the reflective subject in a deliberative process involving will. For the existentialist, action is determined subjectively, through and by the very living of consciousness. But, according to Sartre's phenomenology, in reflection mode consciousness cannot be a direct agent. In reflection, consciousness merely witnesses reflected consciousness, becoming aware of choices lived in that reflected consciousness. This collides with traditional perspectives on the powers of deliberation. But, more significantly, it also signals something of a Copernican revolution. Indeed, what Sartre proposes is to shift human reflection from a stance of agency to a stance of awareness. And this shift resonates significantly in another Copernican-like revolution down the line, from a distinct angle. I refer to António Damásio's inflection of the traditional relation between emotions and feelings. Damásio critiques 
the traditional representation of the relation between emotion and feeling, whereby an inner and private feeling is understood to cause a visible, even public, emotion. In Looking for Spinoza $(2003)^{1}$, Damásio exemplifies this representation with a quote from Shakespeare's Richard II:

Say that again.

The shadow of my sorrow! ha! let's see:

'Tis very true, my grief lies all within;

And these external manners of laments

Are merely shadows to the unseen grief

That swells with silence in the tortured soul;

In a way parallel to Sartre's understanding of will, Damásio puts forward that it is not emotions that are the shadows of feelings, but the other way around. It is feelings, rather, that are the shadows of emotions, in that the former are a conscious perception of the latter. Of course, there is at least one important difference between these two revolutions - for Damásio, consciousness is not a direct role player, whereas for Sartre consciousness certainly is the direct and actually the sole role player of human agency. In the end, both Sartre and Damásio advance a similar claim: that a voluntarist and intellectualised centrality needs to be demystified in our subjective living. Although emotional living is necessarily conscious for one but not for the other, both authors posit that emotional living has significant priority over reflective consciousness.

These two facts - an ontological freedom that must be distinguished from free will, and a reflective will that must be distinguished from the subjectivity that determines action - are obviously decisive in Sartre's conceptualisation of human action, as we will see.

\section{Motives and mobiles}

In the chapter on will and freedom of L'Être et le Néant, Sartre discerns a difference between motives and mobiles of action. That difference is established along the following lines:

- The motive is the reason for action, is objective, and is independent of the subjective aspects of action.

\footnotetext{
1. "We tend to believe that the hidden is the source of the expressed. Besides, we know that as far as the mind is concerned, feeling is what really counts. 'There lies the substance,' says Richard, speaking of his hidden grief, and we agree. We suffer or delight from actual feelings. In the narrow sense, emotions are externalities. But 'principal' does not mean 'first' and does not mean 'causative.' The centrality of feeling obscures the matter of how feelings arise and favors the view that somehow feelings occur first and are expressed subsequently in emotions." (Damásio, 2003: 29)
} 
“On entend ordinairement par motif la raison d'un acte ; c'est-à-dire l'ensemble des considérations rationnelles qui le justifient. (Sartre, 1943: 522)

“Certes, le motif est objectif : c'est l'état de choses contemporain, tel qu'il se dévoile à une conscience.” (Sartre, 1943: 524)

- And the mobile is the set of desires, emotions, and passions that drive a subjectivity to perform an action.

"Le mobile, au contraire, est considéré ordinairement comme un fait subjectif. C'est l'ensemble des désirs, des émotions et des passions qui me poussent à accomplir un certain acte." (Sartre, 1943: 522)

Will indeed contains motives or reasons to act, but Sartre has shifted it to an exclusively reflective plane of awareness. Thus motives, while perceived within the realm of will, only appear in reference to a project which gives meaning to an action determined elsewhere (rather than determining action directly from a reflective position, as deliberation would make us suppose). It is this project - where motives are aspects of the world implied in the project - that is pictured in will, through reflection.

Motives are seen only in light of an end, a project of being. Each motive is a certain objective structure of the world, dependent on a certain point of view, the point of view of a certain project towards which the world is mobilised.

These ideas must not, however, lead us to believe that motives have nothing to do with action activation and that action is entirely determined through subjective, internal mobiles. Sartre is very clear on this issue, stating that to the positional awareness of motives or reasons to act in reflection corresponds a non-thetic self-consciousness as mobile - a more or less passionate project towards an end. Motives and mobiles are, in fact, correlative, and both refer to the ends of a project: mobiles as a non-thetic living of the motives.

"Ainsi motif et mobile sont corrélatifs, exactement comme la conscience non-thétique (de) soi est le corrélatif ontologique de la conscience thétique de l'objet. De même que la conscience de quelque chose est conscience (de) soi, de même le mobile n'est rien d'autre que la saisie du motif en tant que cette saisie est conscience (de) soi. Mais il s'ensuit évidemment que le motif et la fin sont les trois termes indissolubles du jaillissement d'une conscience vivante et libre." (Sartre, 1943: 525-6)

This means three other things:

- Firstly, that Sartre departs from the traditional opposition - easily conceived as a psychological or even moral conflict - between an action determined by motives or reasons to act and an action determined by passionate and emotional mobiles. Reasons or motives do not determine action, except in the sense that they are the reverse side of a complex 
motive/mobile. At the same time, mobiles only have meaning in relation to a world articulated through motives.

- Secondly, that motives, though the content of will, are not based on will. Unreflective action necessarily has both mobiles and motives, even in the absence of will's perception of motives. This position echoes the famous quotation above - when will appears, the die has already been cast, "les jeux sont faits". The precedence is unequivocal: even objective motives precede their reflective appropriation into will.

"L'acte volontaire se distingue de la spontanéité non volontaire en ce que la seconde est conscience purement irréfléchie des motifs à travers le projet pur et simple de l'acte. Pour le mobile, dans l'acte irréfléchi, il n'est point objet pour lui-même mais simple conscience non-positionnelle (de) soi. La structure de l'acte volontaire, au contraire, exige l'apparition d'une conscience réflexive que saisit le mobile comme quasi-objet (...).” (Sartre, 1943: 527-8)

- Thirdly - and despite the illusory or feigned nature of voluntary deliberation ("toujours truquée"), it remains meaningful, holding an indirect function in determining action. When mobiles need to be grasped in a transcendent way.

"Quand je délibère, les jeux sont faits. Et si je dois en venir à délibérer, c'est simplement parce qu'il entre dans mon projet original de me rendre compte des mobiles par la délibération plutôt que par telle ou telle autre forme de découverte (par la passion, par exemple, ou tout simplement par l'action, que révèle l'ensemble organisé des motifs et des fins comme mon langage m'apprend ma pensée). Il y a donc un choix de la délibération comme procédé qui m'annoncera ce que je projette, et par suite ce que je suis. Et le choix de la délibération est organisé avec l'ensemble mobiles-motifs et fin par la spontanéité libre. Quand la volonté intervient, la décision est prise et elle n'a d'autre valeur que celle d'une annonciatrice." (Sartre, 1943: 527)

\section{Internalism versus externalism, but differently}

Sartrean distinctions between mobiles and motives can be contrasted with Bernard Williams' distinction between internal and external reasons of action. According to Williams, reasons for acting are exclusively internal reasons, i.e., reasons contained in one's subjective motivational set. A presumably external reason to do something only determines one's doing so if that is also wanted. But that does not necessarily mean that only internal reasons can be reasons for action. It is one thing to recognise that only internal reasons can determine action, but quite another to suppose that all relevant reasons must be internal. Bernard Williams uses a kind of Occam's razor, cutting external reasons out due to the fact that only internal reasons 
can determine action. However, one could discriminate between, on the one hand, internal reasons that make us act in a certain way; and, on the other hand, a deeper motivation, not directly related with one's wants, desires, and beliefs, yet, nevertheless, influencing one's wants, desires and beliefs. If Williams' point was merely that those external reasons are not able to determine action, even an externalist would agree. If Williams' point was that those external reasons have no power to determine action directly (i.e., determining power assumed in internal reasons), then it is the case that the externalist point of view is rejected. And I would agree. But, even assuming that refusal of externalism, it is not clear that Williams could state that there are only internal reasons. And it is precisely in this context that I find a confrontation with Sartre's perspective to be useful.

For Sartre, mobiles are the means through which action is possibly determined. But at the very same time, mobiles find correlation in motives, or reasons for action. A simple image is that subjective mobiles and objective motives are two sides of the same coin. Having one means having the other. Desires and wants, and whatever is active in Williams' subjective motivational set, is active in the present consciousness of a living presence of the for-itself (pour-soi). For both Sartre and Williams, though not the same, there is one criterion that must be satisfied in order to determine action. And we can consider such a criterion an internalist concept of determination of human action. But here a significant difference must be emphasised. Wants and desires can count as internal for Sartre - not because they belong to a subjective motivational set, but only insofar as they remain present, always contemporary to the present of consciousness. Once they lose their place in the living present, they are neither lost for good, nor absolutely absent. That is why Sartre's distinction between mobiles and motives is quite interesting. Externality and internality are not defined based on having or not having a relation with desires and wants, but on their being or not being in the present living. Employing words and concepts more familiar to Sartre, the criterion consists of transcending or not transcending consciousness. For him, it is crucial to be able to perform two phenomenological tasks: firstly, to recognise when the present of a consciousness is transcended; and, secondly, to identify the consequences that follow from that transcendence, both from the point of view of knowledge and from the point of view of determining action.

\section{Transcendence and action}

At this juncture, it is useful to recall an example Sartre deploys in his seminal La transcendance de l'Ego. Here the philosopher exemplifies with a lived experience of displeasure or repulse directed towards someone. An experience that Sartre refuses to identify with, or even assume to be necessarily motivated by, a psychological state, such as a feeling of hate, or a psychological quality, such as being a spiteful person. 
Through a detailed analysis, Sartre realises that psychological "states" such as hatred or love are constituted only through reflection and in an unsure, doubtful way, unlike emotions such as attraction or repulsion. For example, I can be aware of repulsion and anger towards Peter and, however, not be sure that I hate him. The emotional immediacy of repulsion and anger does not extend to the psychological "states" of hatred. Indeed, adds Sartre, hatred is then a transcendent object that appears to me by the unreflected experience of disgust or repulsion (SARTRE, 1994). Psychological states - of which love and hate are examples - are objects that are transcendent to consciousness, revealing themselves both from an epistemic perspective, as fallible realities, and also from an existential perspective as inert realities, unable to make any determination in the life of consciousness.

\section{Emotions and action}

The small revolution convened by Sartre would not be complete if it focused only on the movement of expelling psychological states and qualities from inner consciousness to transcendence. It was also necessary to reveal the crucially active aspect of emotions, which are not doomed to passive condition of expression. That is precisely what Sartre intended to do in the third and final part of his Sketch for a Theory of Emotions (Esquisse pour une théorie des émotions), where a perspective on emotional life of a consciousness is given in terms of a transformation of how the world presents itself to a subject.

The world presents itself to consciousness as obstacles and difficulties that must be overcome, always involving a coefficient of adversity. According to Sartre, emotions introduce an element of modulation to the meanings of how worldly objects present themselves to consciousness, softening, bypassing, or adapting to adversity. Sartre provides a very simple example of this plasticity: when perceiving that a bunch of grapes is not, after all, at hand, reachable, consciousness transforms its relationship with the world emotionally. The bunch of grapes becomes less attractive - now, it is just a bunch of unripe grapes. Consequently, the world's adversity is mitigated by this emotional divestment. Another example: an emotion like joy is a foretaste of the fruition that the overcoming of distances and adversity will bring, and sadness translates an inhibited relationship to the world, thus inhibiting adversities that potentiate frustration. This plastic modulation changes not so much the world in its objective adversity, but the way we live it.

Since it is not possible to isolate a meaning of the world or of part of it from a reference to a subject's experience of it, and since it is not possible to speak of an adversity of the world except by reference to those who suffer such adversity, emotional life, according to Sartre, in fact introduces a magical ingredient to the relationships with the objects of the world. 


\section{Teleologism of action, not of morals; Deontologism on ethics, but not Kantian}

Motives, mobiles, reasons, emotions, all considered, were all meaningless outside references to a project. This means that Sartre's theory of action is a clear teleologism, and not a determinism, whichever kind we might consider. As the past has no power over the present, it excludes mental causation, as it excludes any other form of determinism over shifting consciousness. For instance, an unconscious drive of consciousness. This teleologism establishes a not-yet-existent future as value and as meaning of all motives and mobiles of action. An enlightening example by Sartre:

"Le mobile ne se comprend que par la fin, c'est-à-dire par du non-existant, le mobile est donc en lui-même une négatité. Si j'accepte un salaire de misère, c'est sans doute par peur - et la peur est un mobile. Mais c'est peur de mourir de faim ; c'est-à-dire que cette peur n'a de sens que hors d'elle dans une fin posée idéalement qui est la conversation d'une vie que je saisis comme "en danger". Et cette peur ne se comprend à son tour que par rapport à la valeur que je donne implicitement à cette vie, c'est-à-dire qu'elle se réfère à ce système hiérarchisé d'objets idéaux que sont les valeurs. Ainsi le mobile se fait apprendre ce qu'il est par l'ensemble des êtres qui "ne sont pas", par les existences idéales et par l'avenir.” (Sartre, 1943: 512)

But whereas I believe we can affirm that Sartre is committed to a teleological theory of action, even to a teleological ontology of human being (as the project is intrinsically ontological), I would not, however, subscribe to the point of view that, for those reasons, or any others, Sartre could sustain a teleological perspective on ethics. On the contrary, there are several elements that point to a Sartrean deontological perspective. But not as Kant conceptualises it. Not as a rule, an imperative, that should be obeyed by the will. If Sartre's ethical perspectives can be approached as deontological, they must be founded on a rather different basis than the one present in Kant's ethics. I will develop this hypothesis - namely, that there is a deontological ethic in Sartre, in spite of its irreducibility, even strangeness, to Kantian deontology.

1. The rather famous example Sartre exposes in his conference Is Existentialism a Humanism? quite clearly reveals the Kantian ambition of giving a universal base to ethical decision, but with the significant difference of making the decision not a rule-obeying procedure, but a decision taken in a context of conflictual choice. Shortly put, radical choices, deep rooted in reality, instead of categorical imperatives, or any other ethics based on obeying a rule. In the example, the conflict is between the values related to caring for an ill mother who needs her son to be close-by, and the values related to the freedom of peoples in a context of war that requires men to fight far away from their homes. This is a radical choice in the sense that it organises all other choices. The radicality of the choice lies in the fact that 
it does not have any roots in others' choices that could support some of the weight of that choice. Sole subjectivity has to choose in a singular concrete situation that, at the same time, is as if it were for all men. In the words of Sartre:

"La première démarche de l'existentialisme est de mettre tout homme en possession de ce qu'il est et de faire reposer sur lui la responsabilité totale de son existence. Et, quand nous disons que l'homme est responsable de luimême, nous ne voulons pas dire que l'homme est responsable de sa stricte individualité, mais qu'il est responsable de tous les hommes."

["The first step of existentialism is to put every man in possession of what it is to submit to the full responsibility of their existence. So when we say that man is responsible for himself, we don't mean that man is only responsible for his strict individuality, but that he is responsible for all men."] (Sartre, 1946: 31)

2. This universality obviously echoes Kantian categorical imperative. After all, Sartre, like Kant, aims at universality by declaring that by being responsible, actors are responsible for all men. But between the two perspectives there is a major difference, I would dare say a tremendous one. Kant restrains individual action to the (ethically required) imperative consideration of universality. Quite the opposite, for Sartre, universality is not a constraining condition but the co-extensive result - emerging from - of the radicality of singular choice.

3. This point is illuminated by a reply Sartre gave to André Gorz in Sartre. Un film réalisé par Alexandre Astruc et Michel Contat, avec la participation de Simone de Beauvoir, Jacques Laurent-Bost et André Gorz, Jean Pouillon. Texte intégral. Paris: Gallimard, 1977.

"J'ai toujours pensé que la moralité existait. Mais elle ne peut exister que dans des situations concrètes, donc elle suppose l'homme réellement engagé dans un monde et que l'on voie ce que devient la liberté dans ce monde. Autrement dit, la Critique de la raison dialectique est la suite de L'Être et le néant, et la morale ne peut venir qu'après. On peut la trouver dans Flaubert, par exemple." (Sartre, 1977: 98)

4. This also means that the subject of the singular universal, often emphasised as a core concept in the late phase of Sartre's philosophy, does not mean a change so much as it means the achievement of a more exact and clear formulation for something that had been under consideration for decades.

From the early 1960s, Sartre came to express this idea in the phrase 'singular universal' and the reverse formulation 'universal singular'. The idea, in summary, is that individuals reflect the universal features of their time and, conversely, that the universals of an age are realised concretely and singularly by individuals. (Crittenden, Paul, The Singular Universal in J.-P. Sartre, 31) 
“Un homme n'est jamais un individu; il vaudrait mieux l'appeler un universel singulier : totalisé et, par là même, universalisé par son époque, il la re-totalise en se reproduisant en elle comme singularité. Universel par l'universalité singulière de l'histoire humaine, singulier par la singularité universalisante de ses projets, il réclame d'être étudié simultanément par les deux bouts"

["For a man is never an individual; it would be more fitting to call him a universal singular. Summed up and for this reason universalised by his epoch, he in turn resumes it by reproducing himself in it as singularity. Universal, by the singular universality of human history. Singular, by the universalising singularity of his projects, he requires simultaneous examination from both ends."] (Sartre, 1971: ix)

5. Reinforcing the strong continuity between the Sartre of the early 40s and the Sartre of the $60 \mathrm{~s}$ and $70 \mathrm{~s}$, it is interesting to remark a parallel between the call of Sartre into authenticity and, later, his defence of a progressive-regressive method. On the one hand, we know that authenticity, as a refusal of bad-faith, implies the movement of a living relation to a nonassimilable transcendence. And, on the other hand, we also know that the progressive regressive method, as a refusal of a pratical-inert rigidification or reification, implies the movement of a living relation between one's singular condition and one's universal inscription.

\section{Character on ethics, but not following Aristotle}

Keeping in mind these remarks, it is important to emphasise another contrast, now with Aristotelian ethics. In fact, at least three major departures can be highlighted:

1. While Aristotle emphasises a resting point, or a point of equilibrium achievable through his popularised "golden mean", Sartre emphasises relentless, unstoppable movement both between the for-itself and the initself and between the singular and the universal.

2. While Aristotle estimates proiaresis as a deliberation that drives to a choice, and also estimates choices as a certain species that have voluntary acts as broader genus (Nichom. Eth., 1111b), Sartre, quite in opposition, considers that choices are not at all voluntary acts, as we have seen, and considers, moreover, that choices are not the direct result of deliberations. For Sartre, deliberations are a reflective justification a person gives to her choice. Justification appears only when choice is already made.

3. While Aristotle holds a set of uncreated values, rooted in human nature, for Sartre there are no a priori values, in the same way that there is not a human essence or a human nature. Values are a human creation in the effort to perform a project of being able to give a raison-d'-être to the contingent existence. Consequently, we could say that while in Aristotle choice is moved by a certain frame of values, with Sartre choosing is like practising a free-falling sport. 
Nevertheless, under a certain point of view, we still are able to attempt an approach of Sartre's perspectives to Aristotelian ethics. In fact, in spite of Sartre's refusal to consider the central concepts of "bad-faith", "angst", "responsibility", "authenticity" as ethical concepts in L'Etre et le néant, and in spite of his famous final remarks on the need, after L'Etre et le néant, to carry out ethical research, those very same concepts of "bad-faith", "angst", "responsibility", "authenticity" have a strong and unavoidable ethical relevance. Specifically, the revelation of a certain manner of being and of acting, call it authenticity or otherwise, make it relevant; but what truly is at stake here is one type of character instead of another, and not an ethics based on the principle of rule obedience. In other words, instead of an ethical evaluation of acts in themselves or of consequences, as with Kantian and utilitarian ethics respectively, for Sartre there is an undeniable ethical relevance presumed in his considerations on the character of a subject. And, in this sense, there is a sort of ethics of virtue, even if it is radically different from the Aristotelian proposal.

One commentator - Jonathan Webber (European Journal of Philosophy, 14, 1, 2006) - drew attention to this aspect and did it with such emphasis that his paper on the subject has the title "Sartre's theory of character". Webber remarks:

“Though he rarely uses the terms 'personality', 'character', or 'trait', these notions are at the heart of his philosophical, political, biographical, and fictional writings." (Webber 2006: 94).

Under this perspective, the huge importance of characters in Sartre's plays obviously achieves a whole ethical significance that must be attended to carefully. That is exemplified, for instance, in the character confrontation among the three main characters of the famous Sartre play Huis Clos. Joseph Garcin, Inès Serrano and Estelle Rigault find themselves at the farthest horizon of the moral and existential judgment of each other, and of each one towards him or herself. If the conflictual collision expresses something about the threatening condition of the presence of others, as it is often remarked, it would also be important to show how conflict opens a road along which it becomes possible to reach the true character. Moreover, reaching such a true character (le vrai caractère) is to achieve an understanding of the project that singularises a person. In short, her original choice. That articulation between character and project is explicitly pointed out in Webber's paper:

"Sartre's early view is rather that character traits do not determine behaviour, and are within the agent's control. Character traits, on this view, ultimately result from the projects one has chosen to pursue in life, and since one can change these projects one can change one's character traits." (Webber, 2006: 98)

After all these important aspects, and simply as a side comment, I would remark that I do not agree with Webber that Sartre's early view, being 
replaced by the Critique de la raison dialectique view, was rejected "as an inappropriate description of the ways in which projects and hence character traits are adopted and revised" (p. 98). On the contrary, I believe there is a strong solidarity between the two periods, attested to by the continuous prevalence of freedom as core concept in Sartre's philosophy. I do however agree with Webber's claim that there is at least continuity in "his theory of the relation between character traits and projects" (ibidem).

\section{Conclusion: the duty of character}

Somehow, even from a Kantian perspective, there is a sensitive issue around the character. Following the categorical imperative should be a rule assimilated by moral agents as a trait of their character. We could put this idea in very simple terms: for Kant, there is a concern in promoting a character of duty. But for Sartre, quite the opposite is at stake: not a character of duty, but a duty of character. Not in the sense of a certain character instead of another - of course there are bad characters - but rather in the sense that radical investment in pursuing a choice, undertaking a project, and developing a singular character is fundamentally an ethical realisation. Perhaps this is just wishful thinking, but it is also probably the deepest legacy of existentialism to ethics.

\section{References}

CRITTEnden, Paul, 1998. "The Singular Universal in Jean-Paul Sartre". Literature and Aesthetics 8: 29-42.

DAMÁSIO, A., 2003. Looking for Spinoza: Joy, Sorrow and the Feeling Brain. San Diego: Harcourt books.

SARTRE, Jean-Paul - 1936. La transcendance de l'Ego. Esquisse d'une description phénoménologique. Paris: Vrin, 1992.

- 1939. Esquisse pour une théorie des émotions. Paris: Le livre de Poche, 2000.

- 1943. L'Être et le néant. Paris: Gallimard/Tel, 1994.

- 1945, Huis Clos in Sartre, 2005. Théâtre complet. Bibliothèque de la Pléiade ( $\left.{ }^{\circ} 512\right)$, Gallimard.

- 1946. L'existentialisme est un humanisme. Paris: Gallimard/Folio, 1996.

- 1960. Critique de la raison dialectique. Paris: Gallimard/ Bibliothèque de Philosophie, 1985.

- 1971. L'Idiot de la famille (vol. 1). Paris: Gallimard, 1988. 
SHAKESPEARE, William, 1595. Richard II. London, Penguin classics, 2015.

WEBBER, Jonathan, 2006. "Sartre's theory of character" European Journal of Philosophy, 14, 1.

WILliAMS, Bernard, 1985. Ethics and the limits of philosophy. Cambridge, Ma: Harvard University Press.

Sartre. Un film réalisé par Alexandre Astruc et Michel Contat, avec la participation de Simone de Beauvoir, Jacques Laurent-Bost et André Gorz, Jean Pouillon. Texte intégral. Paris: Gallimard, 1977. 